Journal of Social Science and Humanities, 4 (3): 08-13, 2021

e-ISSN: 2600 - 9056

(C) RMP Publications, 2021

DOI: $10.26666 / \mathrm{rmp}$.jssh.2021.3.2

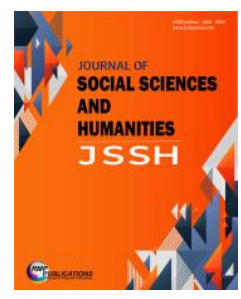

\title{
Wood Carving on Mosque's Pulpits in Terengganu: A Study of Wood Carving Design Motifs
}

\author{
Noor Hafiza Ismail ${ }^{1}$, Hamdzun Haron ${ }^{2}$ and Narimah Abd. Mutalib \\ ${ }^{1}$ Fakulti Seni Lukis \& Seni Reka, Universiti Teknologi MARA (UiTM), Malaysia \\ ${ }^{2}$ Pusat Citra Universiti, Universiti Kebangsaan Malaysia (UKM), Malaysia \\ ${ }^{3}$ Bukit Changgang Primary School, Banting, Selangor
}

\begin{abstract}
A mosque is one of the many respected places of praying for the Muslims. It is one of rendezvous used by the Muslims for religious occasion like sermons, meetings and more. Nations around the world each has their own design to the pulpit of the mosques, basing on their own culture and ethnicity. Terengganu is one of the states in Malaysia that has possession a variety of unique and interesting carvings on a mosque's pulpits. The question now is what are the motifs used in the wood carvings of the mosques' pulpits in Terengganu? In explaining the answer, qualitative description was used to acquire accurate information. Interviews and observations were also used to enhance the data acquired from both primary and secondary sources. The research found that each of the designs produced used a variety of motifs that had both written and non-written messages. The products of these wood carvings are evidence of the Malay's craftsmanship that should be preserved. It is hoped that this research would provide information to the public of the importance of preserving cultural heritage that gave identity to an ethnicity.
\end{abstract}

Key words: Motifs, Art, Wood Craving, Pulpit, Mosques

\section{INTRODUCTION}

The spreading of Islam in the Middle East escalated to South East Asia and continued to spread in Malaya with the introduction of mosques there. Its introduction to South East Asia began at the beginning of Hijra'with the discovery of the Inscription Stone, written in Arabic, dated 1082 or 1102 AD in Gresik, Java (Mohd Jamil Mukmin, 1992). Mosques construction were used to spread Islam teachings among the locals in Malays and its surroundings. The constructions follow the Islam Sharia but also took elements from the Malays' surroundings at that time. Mosques were built using easy to access materials like wood. The construction of mosques from wood would later on influenced the population to decorate the mosques with a variety of designs and patterns. Beautiful and interesting Malay craftsmanship and art would decorate each corner of the mosques. The designs were influenced by a variety of motifs and symbols. Each mosque constructed had their own unique identity, as shown in the level of creativity to exhibit the Malay lifestyle by the designers.
Terengganu us one of the many states situated in the East Coast Peninsular Malaysia that possess a governing central near the beach. All state management is centralized to one place to ease its administration. The main administration related to religion is handled by MAIDAM (Literally Terengganu Religion and Malay Custom Council). Any business related to the construction of mosques or surau is under the supervision of this council. One of the oldest mosques made of wood was constructed during the rule of Sultan Zainal Abidin II. All form of mosque enlargement was done in $1319 \mathrm{H}$ or $1901 \mathrm{AD}$ during the rule of Sultan Zainal Abidin III. However, the building's original construction that was built of wood was replaced by material made of stone during the rule of the new ruler Almarhum Baginda Sultan Umar. The final improvement was in 1972 where one of the main towers were built resembled the towers at Kuala Lumpur National Mosque. 


\section{LITERATURE REVIEW}

\section{Evolution of Mosques}

The mosque is one of the Islam architecture started during the Prophet's time to serve as a praying place to God. Its construction also serves a number of functions that provides harmony to human beings as well as uniting them from any outside influence that could interfere peace in daily lives. The evolution of mosques around the world give way to the existence of smaller mosques in other countries thanks to the spread of Islam worldwide. The advent of Islam to the Malay archipelago was mainly due to the trade with the Arabs. The economic factor through trade directly influenced the locals to embrace Islam. This resulted from this bond between the Arab traders and the locals (Mohd Jamil Mukmin, 1992). The role by both traders and preachers contributed to their openness in spreading Islam (Mohammad Redzuan Othman, 2005). The spreading of Islam and the construction of mosques in Malaya further increased the influence of Islam. Islam could rapidly spread through religion education thanks to the construction of mosques by the locals.

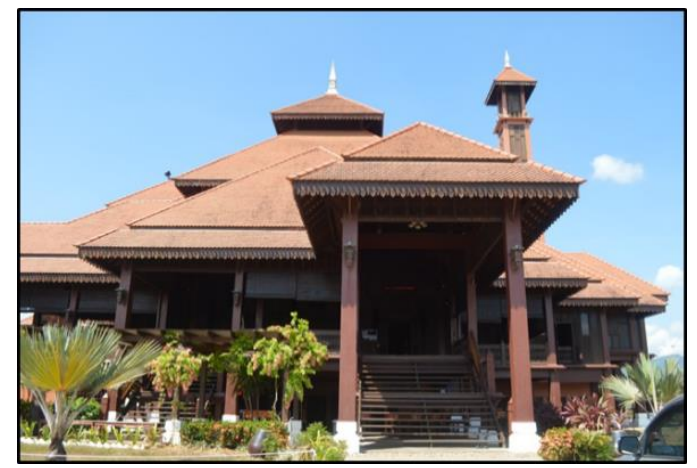

Picture 1 Mosque craftmanship in Terengganu produced from wood that exhibits the Malay art

\section{Islamic Craftmanship Properties}

There are several types of Islamic constructions or buildings that are religious-motivated or secular-motivated in Islamic art. One of the secularmotivated buildings that become an important building is the royal palace. Its architecture was referred to an art for the Islam civilization that exhibits the greatness in its architecture. Initially, mosque construction only consisted of for sides. Throughout time, it slowly gave impact to the mosques. Transformation took place in various but amazing and beautiful mosque forms. It also made way to supplement art like craftsmanship, and calligraphy (Ab. Alim Abdul Rahim \& Syed Idrus Syed
Mat Zin, 1995).

Expressions of peace and solitude are often referenced in Islamic architecture, as stated by Titus Burkhardt. These elements exist as long as they do not oppose either between spiritual and materialistic or between worldly and afterlife. It emphasizes the aspect of high light flow into the buildings as it is one of the aspects emphasized by Islamic architecture. It is in accordance to the environment in providing comfort and tranquility for the Muslim to pray to the All Mighty. Another aspect that is emphasized in Islamic architecture is related to indoor and outdoor decoration like wall decoration. The most commonly used decoration in the mosque is calligraphy since it is seen to be more effective and appropriate (Othman Mohd. Yatim, 1989).

Islamic arts expanded from the East to the West. The ever-connected arts have contributed a variety of successful expanding decorations. The caliphs and kings became important figures in the efforts many mosques other that encouraging the development of other artistic forms originating from other artistic works. Despite the uniqueness of Islamic arts in different nations and culture, there existed consistency in the application of tawhid as a basis to the buildings constructed. The approach appointed by the Prophet can be seen is every mosque throughout the world (C. Israr, 1978).

\section{Pulpit}

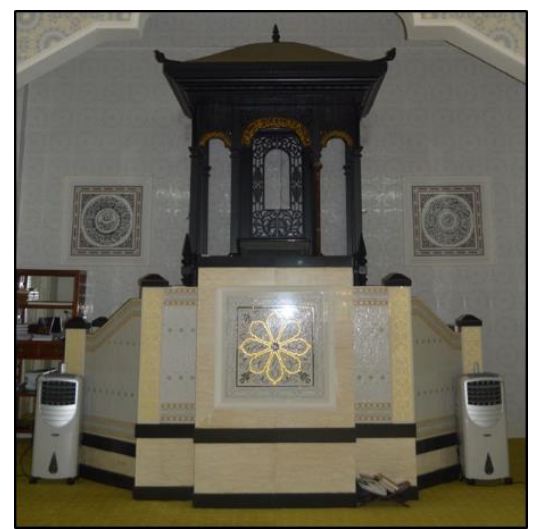

Picture 2 A pulpit example made from wood, with the base made from marble

During the time of the Prophet, the Prophet would sit on the highest level of a tree level pulpit. The pulpit had a specialized role whereby the 'khatib' (preacher) would stay there where delivering summons, most commonly for Friday prayers. It is commonly situated on the right side of the mihrab, made from either wood or concrete. There is also pulpit equipped with small dome that has 
an oval or circle top. Currently, pulpit is no longer limited to three levels. From a philosophical point of view, pulpit is viewed as communication from Heaven.

\section{Craftmanship}

Craftsmanship is held high in Islam that it is admired by the public for having composition arrangement in decoration or motif arrangement craftsmanship. The division in the motif arrangement follows measuring knowledge or mathematic to ensure that the positions for every motif is arranged accordingly Islamic craftsmanship illustrates a harmonized element of unity from different aspects and when observed, thought or felt can deliver the message in the craftsmanship. The arrangement for natural motifs like leaves, roots and flowers commonly follow the style of their designers. The materials used are commonly wood, streamlined terracotta stones and more. It is common that the craftsmanship does not exist on its own as it is one with the art of writing. Thus, it is possible to produce more craftsmanship for decorations in the Islamic craftsmanship buildings (C. Israr 1978).

The craftsmanship cannot be regarded as being produced by art purposes but also to become a beautiful expression. It also provides other deep impact which is a feeling filled with beauty. All forms of beauty will make human closer to the creator as well as to other in their daily lives. The craftsmanship used scriptures from the Koran as well as the hadith and other words of empowerment that are commonly used in different carving motifs. It is common for scriptures for the Koran to be used at the beginning like 'bismillahirahmanirrahim' or 'la ilaha illallah Muhammad Rasullullah'

During the renaissance, craftsmanship that employed sculptures became popular among the public. Not only that it was popular among the Muslims, it also influences Christians in producing their own artists. There are a few churches in Italy that are decorated with craftsmanship ideas like the Milano Church It is visible at the entrance where it is filled with abundant craftsmanship that are arranged properly in Arabic as seen in Islamic buildings. This is proof that Islamic craftsmanship also becomes an art admired by many when most of the churches also used it in their rituals.

\section{Carvings at the Pulpit at Terengganu Mosques}

The carving at a mosque's pulpit is usually made of wood. Its development using wood allows a variety of amazing designs to be used on the wood surface. Its surface is also decorated with different motifs that commonly centralized to flora. It is in accordance to Islamic teachings that forbid the use of living things motifs like animals.

The carving varieties decorating the mosque's pulpit are usually derived from geometric plant forms or cosmos (see Picture 3). The use of living things and animals are not allowed in Islam as according to ulama (scholars), it is rendered to be makruh to use those as expressions. Islam community avoid using living things as motifs as accordance to the Islamic law to avoid such use.

A hadith from Sa'id Ibnu Hasan: "While I was together with Ibn Abbas, a man suddenly comes and says: Yes Ibnu Abbas! I make a living from my hands' hard work which is making arches like this. Thus, Ibn Abbas replied: Nothing that I have said to you is the things that I heard from the Prophet. He decrees: Whoever draws a picture, he will be tortured by God until he gives life but forever he will be unable to give life to the picture" The hadith clearly shows the ban of using any kind of expression in the form of living things. Whoever illustrates animals would be judged later on in the afterlife with God bestowing punishment to those who make a living out of it Thus, Islamic arts and craftsmanship's limit the use of certain motifs in their works of arts (C. Israr 1978).

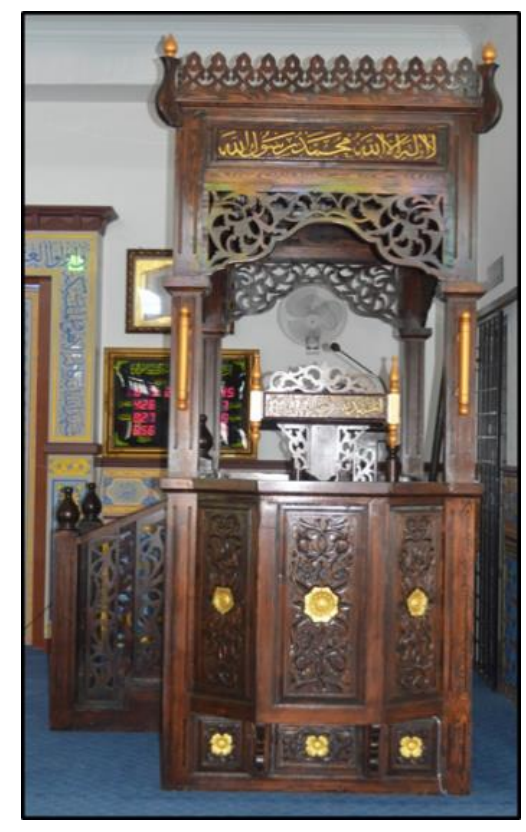

Picture 3 The pulpit's at Masjid Kampung Balai Besar, Dungun is decorated with flora motif and calligraphy. 


\section{Caligraphy Carving}

The spread of Islam throughout the world enables the introduction of Islamic calligraphy to other nations and cultures other than the Arabs. The differences of cultures and ambitions have led to variations in calligraphy. It is adapted to their respective cultures and indirectly leads to other variations in calligraphy styles. Craftsmanship in Islam is of high value that it is admired by others for having composition arrangement in craftsmanship. The divisions in the motif arrangement follow mathematical equation to ensure that the positioning's are arranged to their respective locations Islamic craftsmanship exhibits elements of harmony and unity from different aspects when seen and experienced the message intended in them. However, the craftsmen are behind the fine details of the natural motifs like flowers, leaves and roots. The materials for the craftsmanship are a variety of wood, stone and others. It does usually appear on its own as craftsmanship is related to calligraphy. It can be used to make more craftsmanship for Islamic buildings (C. Israr 1978).

\section{Motif Definition}

The existence of motif is shaped from the image repetitions and also noted from small designs. It is arranged structurally by following a fixed sequence to form a design (Ismail Ibrahim, 2007). Its development can also be related to the arrangement of an object since it involves arranging of organic and geometric designs. The arrangement of the motifs is done repetitively and involves the elements present in the designs like lines, forms, value and colour (Haziyah Husin, 2006). The produced motif done repeatedly will refer to the basic design that refers to the produced motif itself. This will eventually produce a new design commonly known as 'all over pattern'. It can be seen here that motifs are stationary without the presence of the produced designs.

Malay arts will not be complete without interesting and unique motif and designs on its produced art surface, whether they are wood carvings or something else. Traditional Malay motifs can be divided into two that consist of decoration motifs and finishing motifs that act as the decorations to the produced object. Their developments are closely influenced by the traditions and customs that the Malays inherited (Abdul Halim Nasir, 1986). Society cannot distinguish a nation's identity and ethnic without motifs. A nation is recognized from the uniqueness and difference of their motifs that show the expertise and knowledge that it has in producing an artwork admired by others. These decoration motifs can also differentiate the arts exist in different areas, districts, and states in Malaysia in addition to becoming a characteristic to an object and the weaving produced from it. The development of such motifs shows how the earlier Malay society was detailed in their creativity in creating motifs from the weaving. The production of this motif can elevate Malay weaving craftsmanship to a new level and be appreciated as the process tends to be complicated. Without experiencing the hardships and difficulties in producing weavings from the easiest to the hardest, we may not be able to differentiate the weaving motifs from other countries. Its production can also turn a carving into becoming more interesting when it is combined with art elements in designs.

\section{Types of Wood Carving Motifs}

Motifs produced on carvings are results from craftsman in the process of making carvings to objects. Its makeups will from various designs and motifs following the intended colouring. The various motifs produced functions as a form that gives beauty to the produced objects and equipment. Motif production serves a certain function other than providing beauty to the produced equipment. One example is the translucent carving on the roof lattice and a window is to allow wind circulation and light into the house (Hamdzun Haron 2013).

The picture 4 below shows an example of a pulpit of a mosque in Terengganu that is produced using plant motifs that are allowed in Islam.

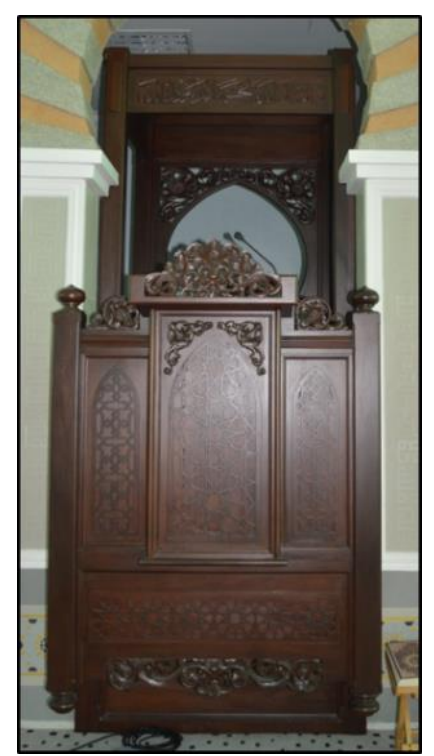

Picture 4. A mosques' pulpit at Masjid Kampung Limbongan, Besut, Terengganu

It shows that the use of living motifs is forbidden in any form of art, especially in Islam arts. Its 
motifs consist of three motifs that are consistent with the designs on the produced pulpit. It resembles the first pulpit used by the Prophet that consists of only three levels. The use of three levels on the pulpit is more practical for the khatibs who are giving the sermons. It is because of the majority of the pulpits produced use to many levels that would hinder the submission of oneself to Allah. It is also made of wood that are fully decorated with 2 dimensional translucent and non-translucent carvings. The carving produced usually combines these two designs to produce a variety in the carvings to appear more interesting from the different compositions.

\section{FINDING AND DISCUSSION}

\section{Carving Motifs on Mosque Motifs in Teregganu Mosque}

Geometric motifs are commonly used for items in the Malay arts like pottery, tepak sirih and the sheath for Keris (Wan Hashim Wan Teh, 1990). Its freemotivated motif is limited to circle or pointed designs. The process to make these geometric motifs in Islam arts are more inclined towards repetitions in order to give life to them. They are usually connected and combined with other decorations filled with plant motifs or calligraphy (Ros Mahwati Ahmad Zakaria 2009). The geometric motif is production that relies on mathematics'. The relationship between these two designs gave way to various techniques for making new motifs or building mosques (Roshdi Rashed 1992).

The carvings at the mosques' pulpits in Terengganu incorporate carving motifs from flowers, cosmos, calligraphy and fauna. The calligraphy is often used with flower motifs for each of the produced carvings. Besides that, the motifs used are sometimes produced independently or with combined flower motifs. However, most of the carvings are more inclined towards combinations since they illustrate the Malay society in their daily lives, quoted as "Tajam Tidak Menujah Lawan" (Sharp without Thrusting Foe). The quote is evident on the ends and sides of the plant motifs that are connected to other leaves in the carvings that would always bow down, symbolizing against conflicts. Each bowing leave symbolized the Malay society that respects one another (Malaysia Craft, 2009).

The carvings at the mosques' pulpits in Terengganu incorporate carving motifs from flowers, cosmos, calligraphy and fauna. The calligraphy is often used with flower motifs for each of the produced carvings. Besides that, the motifs used are sometimes produced independently or with combined flower motifs. However, most of the carvings are more inclined towards combinations since they illustrate the Malay society in their daily lives, quoted as "Tajam Tidak Menujah Lawan" (Sharp without Thrusting Foe). The quote is evident on the ends and sides of the plant motifs that are connected to other leaves in the carvings that would always bow down, symbolizing against conflicts. Each bowing leave symbolized the Malay society that respects one another (Malaysia Craft 2009).
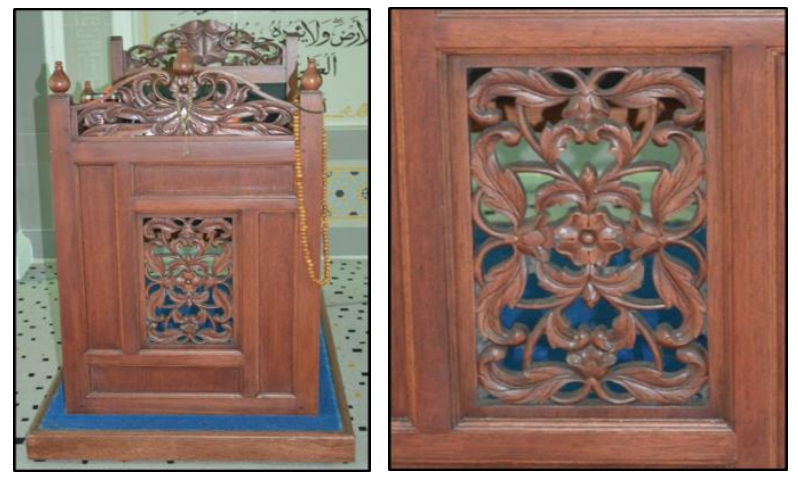

Picture 5. Illustration of the carving motifs on the mosque's motifs referring to the quote 'Sharp without Thrusting Foe'

\section{CONCLUSION}

The spectacular craftsmanship's used on the mosques in Terengganu show. The accuracy and expertise of the craftsmen in producing a variety of unique and interesting designs. Using symbols and emblems also show a high thinking level that emphasis on the society's culture in the form of art. Muslim craftsmen produce unique craftsmanship that shows the level of the thinking that they have, with their works containing both written and implicit messages. It shows the level of details in Islamic art in illustrating to others something in detail and delicate. The Malay Muslim art shows a society with a high level of respect. The intended message is delivered is not directly expressed but uses indirect expressions. It is one of the many ways to be considerate to the people around them. It has also made the society to think deeply and has given way for society to become creative and innovative. It can be concluded that majority of the pulpit at the mosques in Terengganu use motifs derived from natural flora around their accommodations such as the hibiscus. Moreover, the use of living motifs like animals in the wood carvings were omitted earlier since it is forbidden in Islam art. 


\section{REFERENCES}

[1] Haron, H., Yusof, N. A. \& Mutalib, N. A., Factors influence on personal practical artwork. $1 \mathrm{Dec}$ 2014, In: Mediterranean Journal of Social Sciences. 5, 27, p. 1482-1494.

[2] Ab. Alim Abdul Rahim \& Syed Idrus Syed Mat Zin. 1995. Tamadun Islam.Selangor: Fajar bakti Sdn. Bhd.

[3] Abdul Halim Nasir. 1995. Seni Bina Masjid di Dunia Melayu-Nusantara. Bangi: Penerbit Universiti Kebangsaan Malaysia

[4] C. Israr. 1978. Sejarah Kesenian Islam:Jilid 1.Jakarta:Penerbit Bulan Bintang

[5] Hamdzun Haron. 2013. Akal Rekaan Pandai Seni Warisan Melayu. Selangor: Institut Alam dan Tamadun Melayu

[6] Haziyah Hussin. 2006. Motif Alam dalam Batik dan Songkek Melayu. Kuala Lumpur: Dewan Bahasa \& Pustaka.

[7] Ismail Ibrahim. 2007. Warisan Motif \& Corak Etnik Sabah. Sabah: Universiti Malaysia Sabah.

[8] Kraftangan Malaysia (2009). Ukiran Kayu Warisan Melayu. Kuala Lumpur: Perbadanan Kemajuan Kraftangan Malaysia.

[9] Mahyudin Yahaya. 2005. Tamadun Islam. Selangor: Penerbit Fajar Bakti Sdn. Bhd.
[10] Mohammad Redzuan Othman. 2005. Islam dalam Masyarakat Melayu: Peranan dan Pengaruh Timur Tengah. Kuala Lumpur: Penerbit Universiti Malaya.

[11] Mohd Jamil Mukmin. 1992. Sejarah Perkembangan Islam. Kuala Lumpur: Nurin Enterprise.

[12] Mohd Johari Ab. Hamid. 2004. Falsafah dan Kritikan Seni. Tanjung Malim: Universiti Pendidikan Sultan Idris.

[13] Mohd Nor Jusoh. 2003. Tamadun Islam. Kelantan: Dian Darulnaim.

[14] Othman Mohd. Yatim. 1989. Warisan Kesenian Dalam Tamadun Islam. Kuala Lumpur: Dewan Bahasa dan Pustaka.

[15] Ros Mahwati. 2009. Motif Hiasan Tiga Buah Masjid Tua Abad Ke-18 di Melaka. Tesis Sarjana. Bangi: Universiti Kebangsaan Malaysia.

[16] Roshdi Rashed.1992. Matematik Islam: Tempat Bersilangnya Geometrik dan Algebra. Osman Bakar \& Azizah Hamzah. Sains, Teknologi, Kesenian \& Agama: Perkspektif Pelbagai Agama.12-13. Kuala Lumpur: Penerbit Universiti Malaya

[17] Wan Hashim Wan Teh. 1990. Perkembangan Industri Kraftangan Malaysia. Sari 8:29-48. 